\title{
Climate change, cattle, and the challenge of sustainability in a telecoupled system in Africa
}

\author{
$\underline{\text { Tara S. Easter }}^{1}, \underline{\text { Alexander K. Killion }}^{1,2}$ and Neil H. Carter $^{1}$
}

\begin{abstract}
Information, energy, and materials are flowing over greater distances than in the past, changing the structure and feedbacks within and across coupled human and natural systems worldwide. The telecoupling framework was recently developed to understand the feedbacks and multidirectional flows characterizing social and environmental interactions between distant systems. We extend the application of the telecoupling framework to illustrate how flows in beef affect and are affected by social-ecological processes occurring between distant systems in Africa, and how those dynamics will likely change over the next few decades because of climate-induced shifts in a major bovine disease, trypanosomosis. The disease is currently wide-spread in Africa, affecting millions of cattle every year and resulting in massive economic losses. Increasing temperatures are predicted to substantially reduce the geographic range of the cattle disease by 2050 in regions of Africa, thereby potentially releasing cattle from disease control in those areas. Despite the societal and economic benefits, greater cattle production can also lead to significant environmental degradation. Our investigation takes a qualitative, yet systematic, approach to explore how changes in the regional distribution of cattle production, caused by shifts in the bovine disease, will affect the social and ecological conditions of the telecoupled system in the future. Doing so lays the groundwork to quantify telecouplings and improve decision making under uncertainty in the future.
\end{abstract}

Key Words: cattle; climate change; social-ecological systems; telecoupling

\section{INTRODUCTION}

Human societies and ecosystems around the world are fundamentally interlinked, creating integrated systems of feedbacks affecting both ecosystem resilience and human wellbeing (Liu et al. 2007). Research on coupled human and natural systems is rapidly advancing to understand relationships between social and ecological conditions and outcomes (Ostrom 2009). This research has shown that information, energy, and materials are flowing over greater distances than in the past, changing the structure and feedbacks within and across coupled systems worldwide (Liu et al. 2015). Globalization and expansion in the human population are driving increases, for example, in global trade, the spread of exotic species, and the transfer in technologies (Liu et al. 2013). The changing flows are increasingly connecting socioeconomic and ecological systems that are distant from each other through various human-environment interactions (Liu et al. 2016). Given these increasing interactions over distances, examining coupled systems in isolation overlooks crucial dynamics and limits the ability of researchers to predict changes in the future (Carter et al. 2014). For example, the flow of information and technology from traders in Vietnam and China caused unanticipated changes in the hunting behaviors of people living near a protected area in Cambodia (Carter et al. 2017). The changing dynamics of flows therefore challenge researchers and decision makers to understand the catalysts for these changes and their implications on sustainability.

Recently, a telecoupling framework was introduced to help guide interdisciplinary research on the social and environmental causes and consequences of these flows over distances (Liu et al. 2013). This framework allows for the systematic analysis of the causes, effects, agents, and dynamics of these flows. Consequently, a number of studies have started using this framework to understand complex social-ecological interactions and feedbacks between coupled systems that are distant from each other, and to organize research and management priorities (Bruckner et al.
2015, Friis et al. 2016, Gasparri et al. 2016). Here, we extend the application of this framework by using it to investigate how trade flows in beef between coupled systems in Africa, where demand for animal-based protein is projected to grow rapidly, might change in the next few decades. We then discuss the potential social and ecological consequences of those changes. In particular, we explore how future climate-induced shifts in the geographic range of a disease affecting cattle might instigate changes to important social and ecological characteristics within the telecoupled system.

Climate change is expected to alter the ranges and virility of many globally significant diseases, e.g., malaria (Patz and Olson 2006) and dengue fever (Åström et al. 2012). One such disease is African trypanosomosis (trypanosomiasis in humans), which occurs throughout sub-Saharan Africa and is deadly for both humans and animals, especially cattle (Bouyer et al. 2015). In the following, we focus on how forecasted shifts in the geographic range of the disease caused by climate changes over the next half century in southern and eastern Africa might alter cattle production patterns, which has ramifications for human wellbeing and environmental sustainability. As such, we do not discuss explicitly the effects of this range shift on patterns of the human disease, which certainly would have both social and environmental implications, but is beyond the scope of this paper. We also do not investigate climate-induced changes in other livestock diseases (Thornton et al. 2009), such as foot-and-mouth (Dion and Lambin 2012). Instead we focus on trypanosomosis because it is widespread across the continent, affects large numbers of cattle, and a great deal of information about the disease exists, including sensitivities to climatic variables.

Our primary aim is to use the telecoupling framework to illustrate how flows in beef affect and are affected by social-ecological processes occurring between distant systems, and how those dynamics will likely change over the next few decades because of 
climate-induced shifts in bovine trypanosomosis. By synthesizing studies from a wide range of disciplines, we describe where the systems are that will be affected, what flows exist between those systems, and who the agents are that direct those flows. Last, based on the best available information, we indicate how a change in one of the causes of those flows might affect the social and ecological conditions of the telecoupled system, while acknowledging that other future scenarios are also possible. Our investigation therefore largely takes a qualitative, yet systematic, approach to reveal interlinkages over distances and illustrate plausible future changes. This process of "futuring" can be a useful heuristic for decision makers (Duinker and Greig 2007). Furthermore, it lays important groundwork for transdisciplinary project design to quantify and manage system interlinkages, especially those projected to shift because of climate change.

\section{Social and environmental impacts of livestock production}

Livestock production is the world's largest anthropogenic land use, accounting for nearly $75 \%$ of all agricultural land and $30 \%$ of the Earth's ice-free surface (Steinfeld et al. 2006, Herrero et al. 2013). Between 2000 and 2050, the global cattle population is estimated to increase over $70 \%$ from 1.5 billion to 2.6 billion, with most of that growth occurring in developing countries (Rosegrant et al. 2009). The total demand for livestock products in Africa is expected to almost quadruple by 2050 , in large part to help feed the over 1.2 billion more people projected to be added to the continent during that time (FAO 2017).

Livestock provide numerous economic and social benefits. The livestock sector employs at least 1.3 billion people globally and directly supports the livelihoods of 600 million smallholder farmers in developing countries (Thornton 2010). In Africa, over $50 \%$ of rural households are dependent on livestock for their livelihoods (FAO 2017). In addition to providing animal proteins, livestock rearing facilitates other types of agricultural production. For example, mixed crop-livestock systems produce half the world's cereals (Herrero et al. 2010). However, livestock production is resource-intensive and presents a major challenge to biodiversity conservation. About half of the world's production of grain ( 77 million tons of plant protein) are fed to livestock to produce 58 million tons of animal protein (Steinfeld et al. 2006). Feed crops for livestock alone account for half a billion acres of land, while livestock production occupies fourfifths of all agricultural land, creating conflict over space and resources (Steinfeld and Gerber 2010). For example, the persecution of large carnivore species, such as lions (Panthera leo) and grey wolves (Canis lupus), worldwide is largely in response to the threats these animals pose to livestock (Ripple et al. 2014). Native herbivores also compete with livestock for forage and water (Madhusudan 2004). In addition to direct competition with wildlife, in many regions, livestock production also drives deforestation and contributes over $14 \%$ of all human-induced greenhouse gas emissions (Wassenaar et al. 2007, McAlpine et al. 2009, O'Mara 2011, FAO 2017). Understanding the ramifications associated with livestock production allows for more effective management in locations where cattle might be released from disease control in the future (Mills et al. 2010). This can include identifying areas most appropriate for livestock fencing (Gadd 2012), ensuring the availability of adequate veterinary resources (Perry et al. 2013), developing grazing management plans (Vallentine 2001), or implementing educational programs that reduce human-wildlife conflict (McManus et al. 2015).

\section{Cattle and trypanosoma}

Trypanosomosis is a bovine disease caused by hemoparasites of genus Trypanosoma. Hematophagous, i.e., feeds on blood, tsetse flies of genus Glossina can carry these hemoparasites and are the vectors of the disease. This disease occurs in approximately onethird of Africa's total land area. Of about 165 million cattle in Africa, 50 million are kept in tsetse-infested areas and are therefore exposed to trypanosomosis. The disease causes 3 million deaths in cattle every year in Africa and an economic loss in cattle production of \$1-1.2 billion (FAO 2011). Smallholder cattle producers are particularly affected because access to veterinary services to combat the disease is limited in many parts of subSaharan Africa (Specht 2008). A few trypanotolerant cattle breeds do exist; however, the most successful breed, N'Dama, is indigenous to West Africa and not used in eastern and southern Africa (Kim et al. 2017). Because of the disease's effects on both humans and cattle, the tsetse fly vectors are targeted by a panAfrican eradication campaign (PATTEC).

Despite the prevalence of the disease, a combination of affluence, historical disease eradication, and environmental conditions has enabled some countries, such as South Africa, to commercialize a livestock industry and export beef products to other countries. These unique conditions therefore create a telecoupled system among international importers and exporters of livestock products. However, because of a changing climate, temperatures are expected to rise to levels that are harmful to tsetse reproduction and survival as well as pathogen development (Hargrove 2004, Moore et al. 2012). Recent work has shown that increasing temperatures during the next few decades will substantially reduce the geographic range of one species of the trypanosome parasite in Mozambique (Fig. 1; Moore et al. 2012). Assuming similar range contractions for other Trypanosoma species, bovine trypanosomosis would become less common and cattle production could potentially increase in the country in the future.

Using the telecoupling framework, we aim to use the beef trade between South Africa and Mozambique as a case study for potential future shifts in socioeconomic and environmental conditions caused by climate change. South Africa and Mozambique have strong socioeconomic and environmental interconnections, and both are nested within a global network of actors exchanging information, energy, and materials. Parsing the causes and consequences of these many interrelationships can be a challenging, if not impossible, task without a framework to focus the investigation. Some frameworks, such as the constitutive hierarchies and teleconnection frameworks, have taken on this challenge by creating an architecture by which proximate and distal socioeconomic and environmental drivers of land system change can be described and analyzed (Gibson et al. 2000, Coe et al. 2008). The recent telecoupling framework expands on these frameworks by explicitly capturing the feedbacks and multidirectional flows characterizing interactions between distant systems (Friis et al. 2016). The telecoupling framework therefore allows us to systematically organize existing information from the region to describe social-ecological feedbacks between distant systems and elaborate a number of plausible changes to those feedbacks over time. In our case, we explore changes brought on by climate change in the next half century. First, we must identify key properties of the systems themselves, primarily South Africa, Mozambique, and neighboring countries. 
Fig. 1. Map recreated from data in Moore et al. (2012). It shows the suitable geographical range for Trypanosoma brucei rhodesiense (assuming presence of their vector, tsetse flies) in 2055. The yellow region represents the portion of the predicted future range where the parasite currently exists. The blue area represents the portion of the predicted future range where the parasite does not currently exist and would therefore be expanding into. The pink areas on the map represent currently suitable areas predicted to be too hot for the parasite under future conditions. Additional details on methodology used to create the map can be found in Moore et al. (2012). Although T.b. rhodesiense is responsible for human sleeping sickness and not bovine trypanosomosis, we assume that other Trypanosoma species have similar sensitivities to temperature as T.b. rhodesiense. Indeed, Moore et al. (2012) used some parameters from studies on T. vivax, T. congolense, and T.b. gambiense to model the future distribution of T.b. rhodesiense. Although the future distributions of Trypanosoma species might differ from the predicted changes in the distribution of $T$. $b$. rhodesiense shown here, we expect large-scale, climateinduced range shifts in bovine trypanosomosis to occur with consequences on cattle production and beef trade in the region.

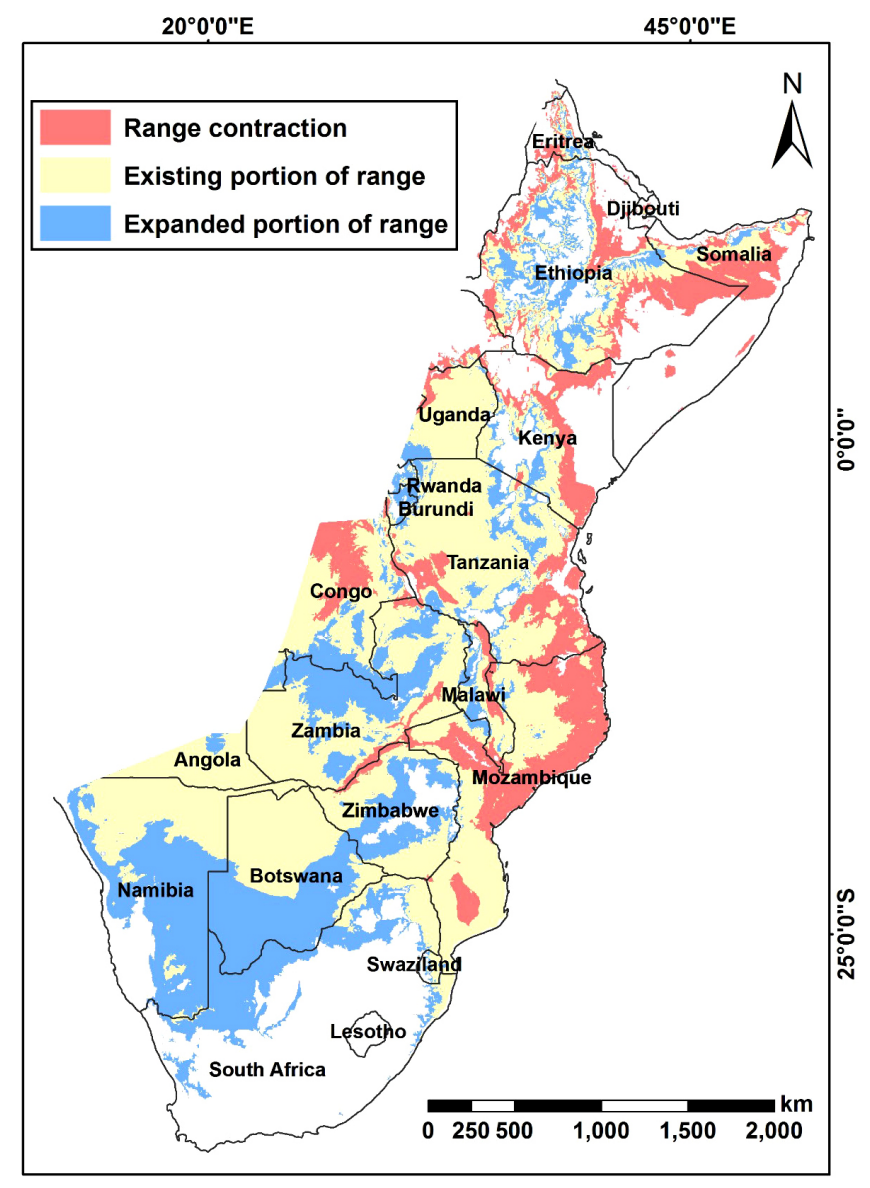

\section{TELECOUPLING FRAMEWORK}

\section{Systems}

The term "systems" in the telecoupling framework refers broadly to the integrated systems in which humans and nature interact. We identified two focal systems for the purpose of this paper: South Africa, a dominant producer and trader of food in subSaharan Africa, and Mozambique, a country with a small but growing agricultural sector that remains reliant on food imports. The system where the majority of flows are being sent from is South Africa, sub-Saharan Africa's largest market (Table 1; Suit and Choudhary 2015). With the region's highest incomes and urbanization rates, production and demand for beef in South Africa have greatly increased in the last decade and livestock production now provides income for over two million people (Homann-Kee Tui et al. 2011, DAFF 2015a).

Mozambique imports much of its beef and livestock from South Africa (Maciel et al. 2013), and is consequently the receiving system of these flows under the telecoupling framework (Table 1). Mozambique is one of South Africa's top importers of all agrifood products (DAFF 2015a), but the reliance on beef from South Africa is especially prominent (Fig. 2). Following the end of Mozambique's civil war in 1992 the country began a cattle restocking initiative in the early 2000s and also imported live cattle from South Africa, but it remains dependent on South African beef to meet protein demands (Maciel et al. 2013). Mozambique has the second lowest density of cattle of any other country in the South African Development Community (SADC; Cunguara et al. 2016) and therefore relies on imports to satisfy the growing protein demands of its over 29 million residents (Homann-Kee Tui et al. 2011).

Fig. 2. The quantity and economic value of South African beef exported to Mozambique from 2001 to 2016 (International Trade Centre 2017).

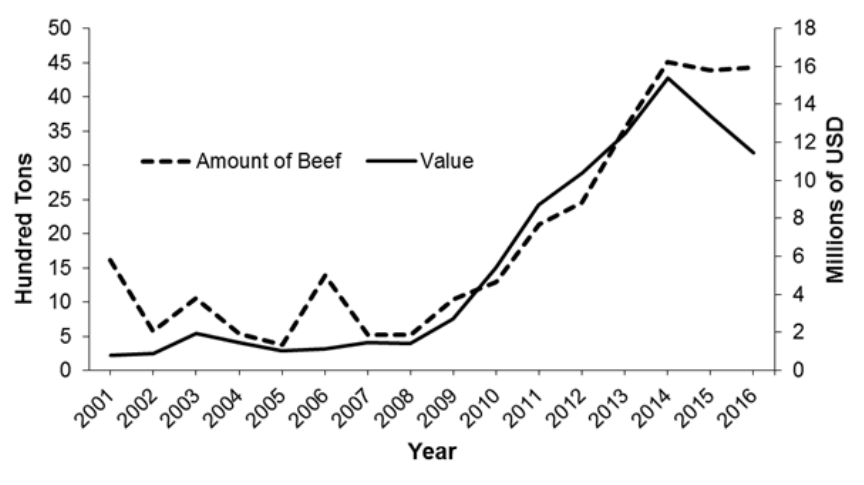

Other countries involved in the production of South African livestock and meat have been designated as spillover systems (Table 1) because their flow of materials, energy, technology, labor, and/or financial resources are affected by their trade with South Africa. Overall, the SADC is consistently a net importer of livestock products (Homann-Kee Tui et al. 2011). South Africa itself also remains a key importer of beef products from neighboring African countries, mainly Botswana and Namibia (Homann-Kee Tui et al. 2011, DAFF 2015b). Other spillover systems include the United States and member states of the 
Table 1. Summary of the telecoupling framework and the major components investigated in the context of a potential range shift of trypanosomosis in southern and eastern Africa.

\begin{tabular}{lll}
\hline \hline Components & Categories & Key Elements and Processes \\
\hline Systems & Sending & South Africa \\
& Receiving & Mozambique \\
& Spillover & Botswana, Namibia, Swaziland, Lesotho, United Nations Member States \\
Flows & Material & Beef \\
& & Trypanosoma parasite \\
& & Tsetse \\
& & Farmers \\
& & Beef market \\
Causes & Environmental & Agricultural institutions \\
& Economic & Mozambique demand for protein \\
& Political & Desire for food security \\
& Environmental & Land cover conversion to agriculture \\
& & Increase in greenhouse gasses \\
& & Soil degradation \\
& Socioeconomic & Poverty alleviation \\
& & Increase in Mozambique beef exports \\
& & Decrease in Mozambique beef imports \\
& & Increase competition for South African beef trade \\
& & Increase in Mozambique cattle feed imports \\
& & Decrease in food aid to Mozambique \\
& & New infrastructure in Mozambique \\
&
\end{tabular}

United Nations that provide a large majority of the food aid to organizations such as the World Food Programme that feed Mozambique in times of food stress (World Food Programme 2017).

Unlike other telecoupling case studies, we posit that the roles of South Africa and Mozambique as sending and receiving systems, respectively, may shift in a changing climate. We identify the flows, causes, and effects of that potential shift.

\section{Flows}

Liu et al. (2013) defined "flows" as the "movements of material, energy, or information between the systems that are transferred as a result of actions taken by agents." We focus on the flows of beef and live cattle in this telecoupled system. The amount and destination of beef exports from South Africa varies from year to year, but has generally risen from 2000 tons of beef exported in 2005 to 28,000 tons of beef exported in 2014. Mozambique has consistently imported the highest amount of beef from South Africa within the SADC (except in 2008) with quantities rising from 580 tons imported from South Africa in 2002 to 4434 tons in 2016 (Fig. 2; International Trade Centre 2017). Although the number of cattle and total beef production have both increased within Mozambique since 1980 (Maciel et al. 2013), some authors believe the country could still accommodate much greater numbers of cattle given the characteristics of the land (Cunguara et al. 2016). The flows of beef and cattle are managed by "agents," many of whom will have to adapt to changes in the future.

\section{Agents}

"Agents," also known as actors, may directly or indirectly facilitate or impede the telecouplings between systems (Liu et al. 2013). Here we focus on the markets and institutions that shape the trade in beef and the shifting disease dynamics that will alter that trade
(Table 1). Markets for domestic, animal-based proteins (milk, meat, and eggs) in Mozambique and in the SADC are important agents driving flows across coupled systems (Table 1; Smith et al. 2013). Generally, livestock rearing is one of the fastest growing agricultural sectors and presents opportunities for poverty alleviation in rural areas of sub-Saharan Africa (FAO 2011, Smith et al. 2013).

Various agricultural institutions are also agents as they allow for the livestock sector to thrive or grow. South Africa's Agricultural Research Council has advanced climate-smart livestock production (improved production efficiency with a lower carbon footprint) and improved cattle breeding success, among other advances in biotechnology, enabling the country to remain one of the largest markets in the region (Agricultural Research Council 2015). Another example is the International Livestock Research Institute, which opened an office in Maputo, Mozambique in 2006 to begin addressing knowledge gaps in livestock rearing in Mozambique and across southern Africa. Among other projects, they are currently working to develop beef value chains by addressing the inability for smallholders to get their cattle to slaughterhouses.

Because livestock production is suppressed by trypanosomosis, the Trypanosoma parasite is also a key agent because it hinders livestock from becoming a sustainable domestic food source or a viable export in various countries, especially Mozambique (African Development Fund 2004, Cunguara et al. 2016). Indeed, trypanosomosis is a major reason why Mozambique is unable to support far greater numbers of cattle (Cunguara et al. 2016).

As vectors of the Trypanosoma parasites, tsetse flies of genus Glossina, are also agents (Table 1). Glossina spp. in South Africa have historically been limited to the northeastern parts the 
country and controlled by rinderpest outbreaks and DDT treatments (Kappmeier et al. 1998). The remaining portion of tsetse-infested areas in South Africa are not a major contributor to the country's beef production. In contrast, two-thirds of Mozambique are infested with the trypanosome-carrying Glossina spp. beginning north of Save River where the "common fly belt" extends through Mozambique, Malawi, Zambia, and Zimbabwe (Specht 2008). The disease is such a hindrance that large tsetse-infested areas of central Mozambique had no cattle at all before the independence and civil wars began in 1970 (Specht 2008). Confirming the continued presence of the disease, following a cattle restocking initiative in the early 2000 s, bovine trypanosomosis cases began increasing, mostly to smallholders known to occupy tsetse fly habitats who lacked cattle husbandry training (Specht 2008). Although disease occurrence has fluctuated over time, climate change represents an unprecedented, large-scale, and significant cause of changes in the geographic ranges of the Trypanosoma parasites.

\section{Causes}

"Causes" are the factors that influence the emergence or change in a telecoupled system (Liu et al. 2013). Because of their strong influences on cattle rearing and beef trade, we highlight climate change and the growing demand for protein as the main drivers of our telecoupled system (Table 1). Although several factors may affect the range of vector-borne diseases in the short term, climate change is expected to heavily modify the suitable range of some parasitic diseases such as malaria, bluetongue, and trypanosomosis (Woolhouse 2006, Thornton 2010, Van Dijk et al. 2010). Climate change is therefore a key cause in our case study (Table 1) because of the strong effect temperature has on the reproductive success and distribution of tsetse flies and the Trypanosoma parasites (Hargrove 2004, Moore et al. 2012). Tsetse pupal development periods decrease with increasing temperatures, and larval production ceases altogether above a certain temperature threshold (Hargrove 2004). Tsetse fly mortality of both pupal and adult flies also increase with temperature (Hargrove 2004). Several studies have shown that temperature is one of the best predictors of tsetse range, predicting tsetse distributions in different regions of Africa with around $80 \%$ accuracy (Rogers et al. 1996, Robinson et al. 1997a,b). Thus, rising temperatures due to climate change will likely have a strong effect on current tsetse distribution and the transmission of trypanosomosis (Moore et al. 2012). Using temperature projections as a predictor of distribution under several climate scenarios, Moore et al. (2012) modeled the response of T. brucei rhodesiense, the parasite responsible for human sleeping sickness, to climate change using the sensitivity of the parasite and their Glossina tsetse vectors to increases in average temperatures.

By assessing the degree of overlap between current distributions of tsetse flies in southern and eastern Africa and current and future T. $b$. rhodesiense ranges, Moore et al. (2012) determined that large areas of Mozambique and other parts of eastern Africa will no longer be suitable for trypanosomiasis transmission in 2055 because of higher temperatures (Fig. 1; Moore et al. 2012). On the other hand, considering only temperature projections, the disease may become more prevalent in portions of Botswana, Namibia, and South Africa (Fig. 1). Given that the model in Moore et al. (2012) used some parameters from studies on $T$. vivax, T. congolense, and T. b. gambiense, we assume that other tsetse and Trypanosoma spp. have similar sensitivities to temperature as $T$. $b$. rhodesiense. Thus, although the future distributions of Trypanosoma species might differ from predicted changes in the distribution of $T$. $b$. rhodesiense, large-scale, climate-induced range shifts in bovine trypanosomosis are likely. These shifts in turn would alter cattle production and beef trade in the region.

In addition to changes to beef/cattle flows caused by likely range shifts in Trypanosoma spp., rising gross domestic products and urbanization in much of Africa is expected to increase consumption of livestock products (Pica-Ciamarra et al. 2013). Compared to the consumption of beef in 2000, sub-Saharan Africa is expected to consume $112 \%$ more beef by 2030 , and Mozambique's consumption is expected to rise by $102 \%$, with only half of that increase caused by population growth (Robinson and Pozzi 2011). As Mozambique's economy grows (Cunguara 2012), so will its demand for cattle and beef, as evidenced by the country's attempts to boost the livestock industry with restocking initiatives (Maciel et al. 2013).

\section{Effects}

The "effects" in the telecoupling framework refer to the actual or potential social-ecological consequences of interactions in a telecoupled system (Liu et al. 2013). Based on previously documented causal relationships, we describe the following as potential effects of a shift in cattle production in southern Africa: poverty alleviation, higher food security, cropland expansion, increase in greenhouse gases, and human-wildlife conflict (Table 1).

In Mozambique, cattle production may be able to persist or increase where it was previously limited by trypanosomosis. There are multifarious effects of a potential shift in livestock and beef trading between South Africa, Mozambique, and throughout the SADC because of newly available areas of land for livestock production in Mozambique. These effects are partly dependent on the different forms an increase in production may take, including intensive feedlot systems, smallholder production, and pastoralism (McDermott et al. 2010). For example, intensive feedlot systems may contribute more pollution and monopolize the economic benefits, whereas extensive cattle rearing may drive more habitat encroachment while providing at least short-term economic opportunity to many. On the other hand, future growth and changes in other large agri-businesses affect market dynamics, such as increased imports of feed or investments in other growing industries from international sources. We aim to highlight several plausible effects from climate-induced shifts in cattle production and trade. Although limited in scope, these descriptions are an important first step in understanding and managing for the many potential socioeconomic and environmental ramifications of a climate-induced shift in trade in a major agri-business within a telecoupled system.

One possible effect of increasing cattle production in Mozambique is to help lift rural communities out of poverty (Smith et al. 2013). It is widely accepted that restocking initiatives provide short-term income support, but if boosting the production of cattle and other livestock is done in a way complementary to social statuses and cultural norms, communities may benefit from a more sustainable source of income and nutrition (Lesorogol 2009). 
Another potential effect of an expansion of cattle rearing in Mozambique and other newly available lands in eastern Africa is an increase in maize and grain imports to the region (Hansen and Gale 2014), which would alter market dynamics among SADC nations and other major exporters such as the USA and EU. On the other hand, utilizing mixed crop-livestock systems could also enable Mozambican farmers to increase the productivity of sugarcane, maize, and other crops through greater use of manure and draft animals (Cunguara et al. 2016). Unlike other regions, the use of draft animals continues to increase in sub-Saharan Africa, enabling a more efficient way to cultivate the land and increase crop yields than without draft animals (Smith et al. 2013). Recognizing these benefits, the potential for Mozambique to expand its use of cattle for traction was analyzed by Cunguara et al. (2016) who found tsetse fly infestations to be a significant hindrance to its adoption.

An increase in cattle rearing and beef production and its associated land use changes could also have significant environmental ramifications. These effects have been well documented in other countries such as in South America (Nepstad et al. 2006) and Southeast Asia (Rudel et al. 2009) and include deforestation (Etter et al. 2006), greenhouse gas emissions (O’Mara 2011), exclusion of native herbivores (Gadd 2012), and retaliatory killing of native large carnivores (Inskip and Zimmermann 2009). Many of these effects could be realized in Mozambique and other portions of eastern Africa where the Trypanosoma parasites are predicted to disappear over the next few decades. For example, an increase in cattle ownership in Mozambique could lead to an increase in human-wildlife conflicts. In neighboring countries with larger livestock industries, livestock depredations by large carnivores are common (Kissui 2008, Gusset et al. 2009, Hemson et al. 2009, Inskip and Zimmermann 2009). In response, ranchers sometimes kill carnivores that they perceive as a threat to their livestock, which can have detrimental effects on carnivore populations (Woodroffe and Ginsberg 1998). Conservationists and land-use planners should therefore consider interventions to mitigate increasing interactions between wildlife and cattle in regions where cattle production might increase because of decreased suppression by bovine trypanosomosis.

As happened in South America, increasing livestock production coupled with cropland expansion can lead to deforestation (Nepstad et al. 2006, 2008) that affects biodiversity and carbon sequestration (Wassenaar et al. 2007, McAlpine et al. 2009). Large numbers of cattle, overgrazing, and removal of forest cover may degrade soil quality, having both environmental and socioeconomic consequences (Herrero et al. 2013). Combined with periods of drought, which sub-Saharan Africa is often vulnerable to, long-term degradation of soil could push local communities toward poverty traps (D'Odorico et al. 2013). However, increasing presence of cattle does not inevitably lead to ecological degradation or decreases in biodiversity. In some systems, pastoralism has promoted the growth of new, nutritious forage that can benefit native herbivores (Reid et al. 2010, NiamirFuller et al. 2012). Furthermore, Herrero et al. (2013) note that agricultural education and scientific advancements might reduce the negative effects of livestock grazing on biodiversity over time through increasing production efficiency (Bouwman et al. 2013).
Another far-reaching consequence of increasing cattle production in and around Mozambique is the increasing use of fencing to control the spread of diseases between wild and domestic ungulate reservoirs. Veterinary fences sprawl across much of southern Africa (Gadd 2012), particularly to control foot-and-mouth disease. The sheer extent of fencing throughout the region has altered the landscape and fragmented habitat for migratory wildlife (Gadd 2012). If the same strategy is utilized in Mozambique, fencing could close corridors between protected areas and alter the movement patterns of already at-risk migratory species, such as elephants, which have been trapped by veterinary fences spanning southern Africa (Chase and Griffin 2009, Cushman et al. 2010, Ferguson and Chase 2010, Jori et al. 2011, Gadd 2012). Additionally, veterinary fencing could hinder the movement of pastoralists in favor of intensive cattle production systems, which are less likely to be environmentally sustainable (Herrero et al. 2013).

\section{CONCLUSION}

We used the telecoupling framework to introduce agents, causes, and social and ecological effects of flows in cattle and beef between multiple systems in sub-Saharan Africa. We also described how the telecoupled system of flows will likely be altered by climate-induced changes in the range of a disease that has drastic effects on both cattle production and human well-being. Currently, the range of trypanosomosis encompasses nearly all of Mozambique. However, under likely climate scenarios much of its range in Mozambique will be reduced. Having the second lowest density of cattle in the SADC, despite the potential to support many more cattle (Cunguara et al. 2016), Mozambique has relied heavily on South African imports to provide agri-food products, particularly beef (DAFF 2015a). The opportunity to raise more cattle in Mozambique, caused by the contraction of the disease range, will have many social and environmental implications both within Mozambique and among its interconnected systems, such as South Africa.

Although not an exhaustive account of all influential interactions and factors, our initial exploration of key elements in the telecoupled system in southern and eastern Africa highlights some important areas for future research efforts. For example, what are the social and environmental trade-offs under conditions of increasing cattle densities in Mozambique, and what should the governance systems look like in order to maximize social benefits while minimizing environmental damage? Also, how will climateinduced changes in other livestock diseases, e.g., rinderpest, footand-mouth, influence the dynamics of the telecoupled system? Quantitatively evaluating such questions is challenging and no consensus has yet emerged regarding which analytical tools are best suited to examine telecoupled systems. However, existing tools from various disciplines show promise, including quantitative analyses of multilayer networks (De Domenico et al. 2013, Kivelä et al. 2014), mathematical models of socioeconomic metabolism, or agent-based modeling of human-environment interactions (Munroe et al. 2014, Friis et al. 2016). Indeed, some mixture of existing tools, such as a regional agricultural model with a local socioeconomic impact model, is likely needed to capture the multisector and multiscalar features of telecoupled systems (Verburg et al. 2016). Integrating these quantitative analytical tools within the telecoupling framework can reveal causal mechanisms that might have been overlooked otherwise and enable better decision making under uncertainty. 
Responses to this article can be read online at:

http://www.ecologyandsociety.org/issues/responses. php/9872

\section{Acknowledgments:}

Research was supported by Boise State University (NSF award number IIA-1301792 from the NSF Idaho EPSCoR Program and the National Science Foundation). We are grateful to Michael Poulos for his critical contribution. We are also grateful to the anonymous reviewers who provided helpful comments. This manuscript is \#1000 from the Boise State University Ecology, Evolution, and Behavior Program.

\section{LITERATURE CITED}

African Development Fund. 2004. Family farming livestock rehabilitation project. African Development Bank Group, Abidjan, Côte d'Ivoire. [online] URL: https://www.afdb.org/ fileadmin/uploads/afdb/Documents/Project-and-Operations/ADFBD-IF-2004-100-EN-MOZAMBIQUE-PCR-FAMILY-FARMINGLIVESTOCK-REHABILITATION-PROJECT .PDF

Agricultural Research Council. 2015. Annual report 2015/16. Agricultural Research Council, Pretoria, South Africa. [online] URL: http://pmg-assets.s3-website-eu-west-1.amazonaws.com/ ARC_Annual Report 2015-16 WEB.pdf

Åström, C., J. Rocklöv, S. Hales, A. Béguin, V. Louis, and R. Sauerborn. 2012. Potential distribution of dengue fever under scenarios of climate change and economic development. Ecohealth 9(4):448-454. http://dx.doi.org/10.1007/s10393-012-0808-0

Bouwman, L., K. K. Goldewijk, K. W. Van Der Hoek, A. H. Beusen, D. P. Van Vuuren, J. Willems, M. C. Rufino, and E. Stehfest. 2013. Exploring global changes in nitrogen and phosphorus cycles in agriculture induced by livestock production over the 1900-2050 period. Proceedings of the National Academy of Sciences 110(52):20882-20887. http://dx.doi.org/10.1073/ pnas. 1012878108

Bouyer, J., A. H. Dicko, G. Cecchi, S. Ravel, L. Guerrini, P. Solano, M. J. B. Vreysen, T. De Meeûs, and R. Lancelot. 2015. Mapping landscape friction to locate isolated tsetse populations that are candidates for elimination. Proceedings of the National Academy of Sciences 112(47):14575-14580. http://dx.doi.org/10.1073/ pnas. 1516778112

Bruckner, M., G. Fischer, S. Tramberend, and S. Giljum. 2015. Measuring telecouplings in the global land system: a review and comparative evaluation of land footprint accounting methods. Ecological Economics 114:11-21. http://dx.doi.org/10.1016/j. ecolecon.2015.03.008

Carter, N. H., J. V. López-Bao, J. T. Bruskotter, M. Gore, G. Chapron, A. Johnson, Y. Epstein, M. Shrestha, J. Frank, O. Ohrens, and A. Treves. 2017. A conceptual framework for understanding illegal killing of large carnivores. Ambio 46:251-264. http://dx.doi.org/10.1007/s13280-016-0852-Z

Carter, N. H., A. Viña, V. Hull, W. J. McConnell, W. Axinn, D. Ghimire, and J. Liu. 2014. Coupled human and natural systems approach to wildlife research and conservation. Ecology and Society 19(3):43. http://dx.doi.org/10.5751/ES-06881-190343

Chase, M. J., and C. R. Griffin. 2009. Elephants caught in the middle: impacts of war, fences and people on elephant distribution and abundance in the Caprivi Strip, Namibia. African Journal of Ecology 47:223-233. http://dx.doi.org/10.1111/ j.1365-2028.2008.01017.x

Coe, N. M., P. Dicken, and M. Hess. 2008. Global production networks: realizing the potential. Journal of Economic Geography 8(3):271-295. http://dx.doi.org/10.1093/jeg/lbn002

Cunguara, B. 2012. An exposition of development failures in Mozambique. Review of African Political Economy 39 (131):161-170. http://dx.doi.org/10.1080/03056244.2012.657881

Cunguara, B., D. Mather, T. Walker, B. Mouzinho, J. Massingue, and R. Uaiene. 2016. Exploiting the potential for expanding cropped area using animal traction in the smallholder sector in Mozambique. Directorate of Planning and International Cooperation, Ministry of Agriculture and Food Security, Republic of Mozambique, Maputo, Mozambique. [online] URL: http://www.fsg.afre.msu.edu/mozambique/RP79E.pdf

Cushman, S. A., M. Chase, and C. Griffin. 2010. Mapping landscape resistance to identify corridors and barriers for elephant movement in Southern Africa. Pages 349-367 in S. A. Cushman and F. Huettmann, editors. Spatial complexity, informatics, and wildlife conservation. Springer, Tokyo, Japan. http://dx.doi.org/10.1007/978-4-431-87771-4 19

De Domenico, M., A. Solé-Ribalta, E. Cozzo, M. Kivelä, Y. Moreno, M. A. Porter, S. Gómez, and A. Arenas. 2013. Mathematical formulation of multilayer networks. Physical Review X 3(4):041022. http://dx.doi.org/10.1103/PhysRevX.3.041022

Department of Agriculture Forestry and Fisheries, Republic of South Africa [DAFF]. 2015a. Agriculture trade performance review. DAFF, Cape Town, South Africa. [online] URL: http:// www.nda.agric.za/doaDev/sideMenu/internationalTrade/docs/itrade/ SA DAFF TradePerfomanceReview Q4of2010.pdf

Department of Agriculture Forestry and Fisheries, Republic of South Africa [DAFF]. 2015b. A profile of the South African beef market value chain. DAFF, Cape Town, South Africa. [online] URL: http://www.nda.agric.za/doaDev/sideMenu/Marketing/Annual $\%$ 20Publications/Commodity $\% 20$ Profiles/field $\% 20$ crops/Beef $\% 20$ market $\%$ 20value $\% 20$ chain $\% 20$ profile $\% 202015$.pdf

Dion, E., and E. F. Lambin. 2012. Scenarios of transmission risk of foot-and-mouth with climatic, social and landscape changes in southern Africa. Applied Geography 35(1-2):32-42. http://dx. doi.org/10.1016/j.apgeog.2012.05.001

D’Odorico, P., A. Bhattachan, K. F. Davis, S. Ravi, and C. W. Runyan. 2013. Global desertification: drivers and feedbacks. Advances in Water Resources 51:326-344. http://dx.doi. org/10.1016/j.advwatres.2012.01.013

Duinker, P. N., and L. A. Greig, 2007. Scenario analysis in environmental impact assessment: improving explorations of the future. Environmental Impact Assessment Review 27(3):206-219. http://dx.doi.org/10.1016/j.eiar.2006.11.001 
Etter, A., C. McAlpine, K. Wilson, S. Phinn, and H. Possingham. 2006. Regional patterns of agricultural land use and deforestation in Colombia. Agriculture, Ecosystems \& Environment 114 (2-4):369-386. http://dx.doi.org/10.1016/j.agee.2005.11.013

Ferguson, K., and M. Chase. 2010. Elephants and fencing conflicts in the GLTFCA and KAZA.TFCA. Pages 173-180 in K. Ferguson and J. Hanks, editors. Fencing impacts: a review of the environmental, social and economic impacts of game and veterinary fencing in Africa with particular reference to the Great Limpopo and Kavango-Zambezi Transfrontier Conservation Areas. Mammal Research Institute, Pretoria, South Africa. [online] URL: http://www.wcs-ahead.org/gltfca grants/pdfs/ferguson final 2010. pdf

Food and Agriculture Organization (FAO). 2011. Mapping supply and demand for animal-source foods to 2030. Animal Production and Health Working Paper. No. 2. FAO, Rome, Italy. [online] URL: http://www.fao.org/docrep/014/i2425e/i2425e00.pdf

Food and Agriculture Organization (FAO). 2017. Africa sustainable livestock 2050. Animal Production and Health Report. No. 12. FAO, Rome, Italy. [online] URL: http://www.fao.org/3/ai7222e.pdf

Friis, C., J. Ø. Nielsen, I. Otero, H. Haberl, J. Niewöhner, and P. Hostert. 2016. From teleconnection to telecoupling: taking stock of an emerging framework in land system science. Journal of Land Use Science 11(2):131-153. http://dx.doi.org/10.1080/1747423X.2015 .1096423

Gadd, M. E. 2012. Barriers, the beef industry and unnatural selection: a review of the impact of veterinary fencing on mammals in Southern Africa. Pages 153-186 in M. J. Somers and M. Hayward, editors. Fencing for conservation. Springer, New York, New York, U.S.A. http://dx.doi.org/10.1007/978-1-4614-0902-1_9

Gasparri, N. I., T. Kuemmerle, P. Meyfroidt, Y. le Polain de Waroux, and H. Kreft. 2016. The emerging soybean production frontier in Southern Africa: conservation challenges and the role of south-south telecouplings. Conservation Letters 9(1):21-31. http://dx.doi.org/10.1111/conl.12173

Gibson, C. C., E. Ostrom, and T. K. Ahn. 2000. The concept of scale and the human dimensions of global change: a survey. Ecological Economics 32(2):217-239. http://dx.doi.org/10.1016/ $\underline{\mathrm{S} 0921-8009(99) 00092-0}$

Gusset, M., M. J. Swarner, L. Mponwane, K. Keletile, and J. W. McNutt. 2009. Human-wildlife conflict in northern Botswana: livestock predation by endangered African wild dog Lycaon pictus and other carnivores. Oryx 43(1):67-72. http://dx.doi. org/10.1017/S0030605308990475

Hansen, J., and F. Gale. 2014. China in the next decade: rising meat demand and growing imports of feed. United States Department of Agriculture Economic Research Service, Washington, D.C., USA. [online] URL: https://www.ers.usda. gov/amber-waves/2014/april/china-in-the-next-decade-rising-meatdemand-and-growing-imports-of-feed/

Hargrove, J. W. 2004. Tsetse population dynamics. Pages 113-138 in I. Maudlin, P. H. Holmes, and M. A. Miles, editors. The trypanosomiases. CABI, Wallingford, UK. http://dx.doi. org/10.1079/9780851994758.0113
Hemson, G., S. Maclennan, G. Mills, P. Johnson, and D. Macdonald. 2009. Community, lions, livestock and money: a spatial and social analysis of attitudes to wildlife and the conservation value of tourism in a human-carnivore conflict in Botswana. Biological Conservation 142(11):2718-2725. http://dx. doi.org/10.1016/j.biocon.2009.06.024

Herrero, M., P. Havlík, H. Valin, A. Notenbaert, M. C. Rufino, P. K. Thornton, M. Blümmel, F. Weiss, D. Grace, and M. Obersteiner. 2013. Biomass use, production, feed efficiencies, and greenhouse gas emissions from global livestock systems. Proceedings of the National Academy of Sciences of the United States of America 110(52):20888-20893. http://dx.doi.org/10.1073/ pnas. 1308149110

Herrero, M., P. K. Thornton, A. M. Notenbaert, S. Wood, S. Msangi, H. A. Freeman, D. Bossio, J. Dixon, M. Peters, J. van de Steeg, J. Lynam, P. Parthasaranthy Rao, S. Macmillan, B. Gerard, J. McDermott, C. Seré, and M. Rosegrant. 2010. Smart investments in sustainable food production: revising mixed croplivestock systems. Science 327(5967):822-825. http://dx.doi. org/10.1126/science. 1183725

Homann-Kee Tui, S., A. van Rooyen, and I. Minde. 2011. National and regional livestock markets: opportunities for growth in $S A D C$. International Crops Research Institute for the SemiArid Tropics, Maputo, Mozambique. http://dx.doi.org/10.13140/ RG.2.1.2879.8968

Inskip, C., and A. Zimmermann. 2009. Human-felid conflict: a review of patterns and priorities worldwide. Oryx 43(1):18-34. http://dx.doi.org/10.1017/S003060530899030X

International Trade Centre. 2017. Trade Map. Meat of bovine animals. International Trade Centre, Geneva, Switzerland.

Jori, F., D. Brahmbhatt, G. T. Fosgate, P. N. Thompson, C. Budke, M. P. Ward, K. Ferguson, and B. Gummow. 2011. A questionnaire-based evaluation of the veterinary cordon fence separating wildlife and livestock along the boundary of the Kruger National Park, South Africa. Preventive Veterinary Medicine 100(3-4):210-220. http://dx.doi.org/10.1016/j. prevetmed.2011.03.015

Kappmeier, K., E. Nevill, and R. J. Bagnall. 1998. Review of tsetse flies and trypanosomosis in South Africa. Onderstepoort Journal of Veterinary Research 65(3):195-203.

Kim, S. J., S. Ka, J. W. Ha, J. Kim, D. Yoo, K. Kim, H. K. Lee, D. Lim, S. Cho, O. Hanotte, et al. 2017. Cattle genome-wide analysis reveals genetic signatures in trypanotolerant N'Dama. BMC Genomics 18(1):371. http://dx.doi.org/10.1186/s12864-017-3742-2

Kissui, B. M. 2008. Livestock predation by lions, leopards, spotted hyenas, and their vulnerability to retaliatory killing in the Maasai steppe, Tanzania. Animal Conservation 11(5):422-432. http://dx. doi.org/10.1111/j.1469-1795.2008.00199.x

Kivelä, M., A. Arenas, M. Barthelemy, J. P. Gleeson, Y. Moreno, and M. A. Porter. 2014. Multilayer networks. Journal of Complex Networks 2(3):203-271. http://dx.doi.org/10.1093/comnet/cnu016

Lesorogol, C. K. 2009. Asset building through community participation: restocking pastoralists following drought in northern Kenya. Social Work in Public Health 24(1-2):178-186. http://dx.doi.org/10.1080/19371910802569740 
Liu, J., T. Dietz, S. R. Carpenter, M. Alberti, C. Folke, E. Moran, A. N. Pell, P. Deadman, T. Kratz, J. Lubchenco, E. Ostrom, Z. Ouyang, W. Provencher, C. L. Redman, S. H. Schneider, and W. W. Taylor. 2007. Complexity of coupled human and natural systems. Science 317(5844):1513-1516. http://dx.doi.org/10.1126/ science. 1144004

Liu, J., V. Hull, M. Batistella, R. DeFries, T. Dietz, F. Fu, T. W. Hertel, R. C. Izaurralde, E. F. Lambin, S. Li, L. A. Martinelli, W. J. McConnell, E. F. Moran, R. Naylor, Z. Ouyang, K. R. Polenske, A. Reenberg, G. de Miranda Rocha, C. S. Simmons, P. H. Verburg, P. M. Vitousek, F. Zhang, and C. Zhu. 2013. Framing sustainability in a telecoupled world. Ecology and Society 18 (2):26. http://dx.doi.org/10.5751/ES-05873-180226

Liu, J., H. Mooney, V. Hull, S. J. Davis, J. Gaskell, T. Hertel, J. Lubchenco, K. C. Seto, P. Gleick, C. Kremen, and S. Li. 2015. Systems integration for global sustainability. Science 347 (6225):1258832. http://dx.doi.org/10.1126/science.1258832

Liu, J., W. Yang, and S. Li. 2016. Framing ecosystem services in the telecoupled Anthropocene. Frontiers in Ecology and the Environment 14(1):27-36. http://dx.doi.org/10.1002/16-0188.1

Maciel, S., A. Okeyo, J. Amimo, M. Scholtz, F. Neser, and M. Martins. 2013. The effect of geographical region of birth on the reproductive performance of the Nguni in southern Mozambique. South African Journal of Animal Science 46:60-63.

Madhusudan, M. D. 2004. Recovery of wild large herbivores following livestock decline in a tropical Indian wildlife reserve. Journal of Applied Ecology 41(5):858-869. http://dx.doi. org/10.1111/j.0021-8901.2004.00950.X

McAlpine, C. A., A. Etter, P. M. Fearnside, L. Seabrook, and W. F. Laurance. 2009. Increasing world consumption of beef as a driver of regional and global change: a call for policy action based on evidence from Queensland (Australia), Colombia and Brazil. Global Environmental Change 19(1):21-33. http://dx.doi. org/10.1016/j.gloenvcha.2008.10.008

McDermott, J. J., S. J. Staal, H. A. Freeman, M. Herrero, and J. A. Van de Steeg. 2010. Sustaining intensification of smallholder livestock systems in the tropics. Livestock Science 130 (1-3):95-109. http://dx.doi.org/10.1016/j.livsci.2010.02.014

McManus, J. S., A. J. Dickman, D. Gaynor, B. H. Smuts, and D. W. Macdonald. 2015. Dead or alive? Comparing costs and benefits of lethal and non-lethal human-wildlife conflict mitigation on livestock farms. Oryx 49(4):687-695. http://dx.doi. org/10.1017/S0030605313001610

Mills, J. N., K. L. Gage, and A. S. Khan. 2010. Potential influence of climate change on vector-borne and zoonotic diseases: a review and proposed research plan. Environmental Health Perspectives 118(11):1507-1514. http://dx.doi.org/10.1289/ehp.0901389

Moore, S., S. Shrestha, K. W. Tomlinson, and H. Vuong. 2012. Predicting the effect of climate change on African trypanosomiasis: integrating epidemiology with parasite and vector biology. Journal of the Royal Society Interface 9 (70):817-830. http://dx.doi.org/10.1098/rsif.2011.0654

Munroe, D. K., K. McSweeney, J. L. Olson, and B. Mansfield. 2014. Using economic geography to reinvigorate land-change science. Geoforum 52:12-21. http://dx.doi.org/10.1016/j. geoforum.2013.12.005

Nepstad, D. C., C. M. Stickler, and O. T. Almeida. 2006. Globalization of the Amazon soy and beef industries: opportunities for conservation. Conservation Biology 20 (6):1595-1603. http://dx.doi.org/10.1111/j.1523-1739.2006.00510. $\underline{\mathrm{X}}$

Nepstad, D. C., C. M. Stickler, B. Soares-Filho, and F. Merry. 2008. Interactions among Amazon land use, forests and climate: prospects for a near-term forest tipping point. Philosophical Transactions of the Royal Society of London B: Biological Sciences 363:1737-1746. http://dx.doi.org/10.1098/rstb.2007.0036

Niamir-Fuller, M., C. Kerven, R. Reid, and E. Milner-Gulland. 2012. Co-existence of wildlife and pastoralism on extensive rangelands: competition or compatibility? Pastoralism: Research, Policy and Practice 2(1):8.

O'Mara, F. P. 2011. The significance of livestock as a contributor to global greenhouse gas emissions today and in the near future. Animal Feed Science and Technology 166-167:7-15. http://dx.doi. org/10.1016/j.anifeedsci.2011.04.074

Ostrom, E. 2009. A general framework for analyzing sustainability of social-ecological systems. Science 325 (5939):419-422. http://dx.doi.org/10.1126/science.1172133

Patz, J. A., and S. H. Olson. 2006. Malaria risk and temperature: influences from global climate change and local land use practices. Proceedings of the National Academy of Sciences 103 (15):5635-5636. http://dx.doi.org/10.1073/pnas.0601493103

Perry, B. D., D. Grace, and K. Sones. 2013. Current drivers and future directions of global livestock disease dynamics. Proceedings of the National Academy of Sciences 110 (52):20871-20877. http://dx.doi.org/10.1073/pnas.1012953108

Pica-Ciamarra, U., D. Baker, N. Morgan, C. Ly, and S. Nouala. 2013. Investing in African livestock: business opportunities in 2030-2050. Livestock Data Innovation in Africa Project. [online] URL: http://www.fao.org/docrep/018/al757e/al757e.pdf

Reid, R. S., C. Bedelian, M. Y. Said, R. L. Kruska, R. M. Mauricio, V. Castel, J. Olson, and P. K. Thornton. 2010. Global livestock impacts on biodiversity. Pages 111-138 in H. Steinfeld, H. A. Mooney, F. Schneider, and L. E. Neville, editors. Livestock in a changing landscape, Volume 1: drivers, consequences, and responses. Island Press, Washington, D.C., USA.

Ripple, W. J., J. A. Estes, R. L. Beschta, C. C. Wilmers, E. G. Ritchie, M. Hebblewhite, J. Berger, B. Elmhagen, M. Letnic, M. P. Nelson, O. J. Schmitz, D. W. Smith, A. D. Wallach, and A. J. Wirsing. 2014. Status and ecological effects of the world's largest carnivores. Science 343(6167):1241484. http://dx.doi.org/10.1126/ science. 1241484

Robinson, T., D. Rogers, and B. Williams. 1997a. Univariate analysis of tsetse habitat in the common fly belt of Southern Africa using climate and remotely sensed vegetation data. Medical and Veterinary Entomology 11(3):223-234. http://dx.doi. org/10.1111/j.1365-2915.1997.tb00400.x

Robinson, T., D. Rogers, and B. Williams. 1997b. Mapping tsetse habitat suitability in the common fly belt of Southern Africa using 
multivariate analysis of climate and remotely sensed vegetation data. Medical and Veterinary Entomology 11(3):235-245. http:// dx.doi.org/10.1111/j.1365-2915.1997.tb00401.x

Robinson, T. P., and F. Pozzi. 2011. Mapping supply and demand for animal-source foods to 2030. Animal Production and Health Working Paper 2. Food and Agriculture Organization, Rome, Italy.

Rogers, D. J., S. I. Hay, and M. J. Packer. 1996. Predicting the distribution of tsetse flies in West Africa using temporal Fourier processed meteorological satellite data. Annals of Tropical Medicine \& Parasitology 90(3):225-241. http://dx.doi. org/10.1080/00034983.1996.11813049

Rosegrant, M. W., M. Fernandez, and A. Sinha. 2009. Looking into the future for agriculture and AKST (Agricultural Knowledge Science and Technology). Pages 307-376 in B. McIntyre, H. Herren, J. Wakhungu, and R. Watson, editors. Agriculture at a crossroads. Island Press, Washington, D.C., USA.

Rudel, T. K., R. Defries, G. P. Asner, and W. F. Laurance. 2009. Changing drivers of deforestation and new opportunities for conservation. Conservation Biology 23(6):1396-1405. http://dx. doi.org/10.1111/j.1523-1739.2009.01332.x

Smith, J., K. Sones, D. Grace, S. MacMillan, S. Tarawali, and M. Herrero. 2013. Beyond milk, meat, and eggs: role of livestock in food and nutrition security. Animal Frontiers 3(1):6-13. http://dx. doi.org/10.2527/af.2013-0002

Specht, E. J. K. 2008. Prevalence of bovine trypanosomosis in central Mozambique from 2002 to 2005. Onderstepoort Journal of Veterinary Research 75(1):73-81. http://dx.doi.org/10.4102/ ojvr.v75i1.91

Steinfeld, H., and P. Gerber. 2010. Livestock production and the global environment: consume less or produce better? Proceedings of the National Academy of Sciences 107(43):18237-18238. http:// dx.doi.org/10.1073/pnas.1012541107

Steinfeld, H., P. Gerber, T. Wassenaar, V. Castel, M. Rosales, and C. De Haan. 2006. Livestock's long shadow: environmental issues and options. Food and Agriculture Organization, Rome, Italy. [online] URL: http://www.fao.org/docrep/010/a0701e/a0701e00. HTM

Suit, K. C., and V. Choudhary. 2015. Mozambique agricultural sector risk assessment. The World Bank Group, Washington, D. C., USA. [online] URL: http://p4arm.org/app/uploads/2015/02/ Mozambique000A00risk0prioritization.pdf

Thornton, P. K. 2010. Livestock production: recent trends, future prospects. Transactions of the Royal Society B 365:2853-2867. http://dx.doi.org/10.1098/rstb.2010.0134

Thornton, P. K., J. van de Steeg, A. Notenbaert, and M. Herrero. 2009. The impacts of climate change on livestock and livestock systems in developing countries: a review of what we know and what we need to know. Agricultural Systems 101(3):113-127. http://dx.doi.org/10.1016/j.agsy.2009.05.002

Vallentine, J. F. 2001. Grazing management. Academic, San Diego, California, USA.
Van Dijk, J., N. D. Sargison, F. Kenyon, and P. J. Skuce. 2010. Climate change and infectious disease: helminthological challenges to farmed ruminants in temperate regions. Animal 4 (3):377-392. http://dx.doi.org/10.1017/S1751731109990991

Verburg, P. H., J. A. Dearing, J. G. Dyke, S. van der Leeuw, S. Seitzinger, W. Steffen, and J. Syvitski, 2016. Methods and approaches to modelling the Anthropocene. Global Environmental Change 39:328-340. http://dx.doi.org/10.1016/j.gloenvcha.2015.08.007

Wassenaar, T., P. Gerber, P. H. Verburg, M. Rosales, M. Ibrahim, and H. Steinfeld. 2007. Projecting land use changes in the Neotropics: the geography of pasture expansion into forest. Global Environmental Change 17(1):86-104. http://dx.doi. org/10.1016/j.gloenvcha.2006.03.007

Woodroffe, R., and J. R. Ginsberg. 1998. Edge effects and the extinction of populations inside protected areas. Science 280 (5372):2126-2128. http://dx.doi.org/10.1126/science.280.5372.2126

Woolhouse, M. E. 2006. Where do emerging pathogens come from? Microbe 1(11):511. http://dx.doi.org/10.1128/microbe.1.511.1

World Food Programme. 2017. Nutritional reporting: IRMA. World Food Programme, Rome, Italy. [online] URL: http://www. wfp.org/fais/reports/irma-by-donor/run/All/All/All/2012/UNITED+ NATIONS 